\title{
Reviving Democracy: Creating pathways out of legitimacy crises
}

\section{Introduction}

Over the last several years democratic citizens and theorists have been grappling with an upsurge in political commentary on the crisis and decline of democratic legitimacy around the world. ${ }^{1}$ Talk of democratic crisis is nothing new; indeed, some have argued that such talk is a pervasive feature of democratic life, in which deep political contestation and ongoing institutional transformation have been historical constants (Tormey, 2014). But these latest crisis diagnoses have particular intensity, marking a jarring end to a long era of democratic ascendancy and consolidation across many world regions. While the field of normative democratic theory greatly expanded its moral and philosophical ambitions through this era, influenced strongly by the theoretical work of John Rawls and Jurgen Habermas, new awareness of democracy's vulnerability to political challenge (or even collapse) is now prompting a different kind of theoretical response. Increasingly, theoretical attention is turning from the philosophical justification of ambitious moral ideals of democracy, to the interpretation of potentials within existing political practice for democratic renewal and repair. $^{2}$

In this review article, I examine three new books at the forefront of this theoretical turn towards engagement with the real-world political dynamics of democratic crisis and revival: Open Democracy: Reinventing Popular Rule for the Twenty-First Century, by Helene Landemore (2020); Hope for Democracy: How Citizens Can Bring Reason Back into Politics, by John Gastil and Katherine Knobloch (2020); and Mending Democracy: Democratic Repair in Disconnected Times, by Carolyn Hendriks, Selen Ercan, and John Boswell (2020). Each of these books is very different in analytical style and prescriptive substance; but together they capture many of the key ideas emerging across the field of democratic theory on the subject of how best to revive declining legitimacy within contemporary democratic orders. In what follows I begin by surveying the contributions of

\footnotetext{
${ }^{1}$ See for example: Przeworski, 2019; Levitsky and Ziblatt, 2018; Mounk, 2018; Runciman, 2018; Norris, 2011; Della Porta, 2013; Papadopoulos, 2013; Howell and Moe, 2020; Rosenblum and Muirhead, 2020.

${ }^{2}$ Both political theorists and political scientists have turned attention to this issue, producing several notable contributions in the last two years alongside those reviewed in detail here including: Tanasoca, 2020; Lafont, 2019; Matsusaka, 2020; Della Porta, 2020.
} 
these new books to debates on this challenging topic - highlighting the importance all attribute to creative political agency as a source of revival in democratic practice. I then discuss several questions left unresolved by these books - concerning the problem of democratic legitimacy, the normativity of democratic standards, and the power dynamics undergirding democratic agency - which jointly mark out an important agenda for future theoretical work on pathways out of democratic crisis.

\section{Building democratic theory from the lessons of creative practice}

The first notable feature of these new books is their shared methodological commitment to deep engagement with creative innovations in democratic practice, as a basis for developing the normative ideals and institutional prescriptions of democratic theory. Viewed from a long-range historical perspective, there is nothing especially novel in this methodological orientation; as the books' authors all recognize, democratic ideas have always been strongly grounded in the problems and practices of real political communities - deriving inspiration from the projects of citizens, in tandem with the speculations of philosophers. But this orientation does contrast with some influential approaches to democratic theory developed through the more recent historical period of democratic ascendancy and consolidation, which followed the liberal-democratic theory of John Rawls (2005) in taking the key tasks of democratic theory to be the elaboration of institutional models that conform to correct moral principles, and the identification of political preconditions for securing their stability. While the new works reviewed here are all still anchored in democracy's defining moral commitments to collective self-rule and political equality, these are not treated as fixed philosophical principles, amenable to one correct interpretation with enduring validity. Rather, democracy's normative ideals are cast as artifacts of a dynamic political history calling for fresh interpretation in each new era and context, as adapted to the predicaments and possibilities confronted there by democratic citizens.

Landemore's Open Democracy adopts a methodological orientation of this kind to develop a systematic articulation and justification of a new normative ideal of 'open' democracy, which builds on her earlier theoretical work on deliberative and epistemic democratic models (Landemore, 2012). Her theoretical analysis focuses on the elaboration of normative concepts and principles - intended to 'inform our mental schema about what to expect from democracy and guide institutional reforms' (Landemore, 2020, 12). But instead of employing 'deductive' analytical methods - deriving normative concepts and principles from some 
grounding philosophical commitments - Landemore here draws instead on 'direct empirical observation of so-called democratic innovations' (primarily from Iceland and France), in what she calls 'inductive political theory' (Landemore, 2020, 20). This is, as she describes it, 'a form of political theory that builds on the generalization, refinement, and deeper exploration of collective intuitions already widely shared in the public as well as those tested on the ground by activists' (Landemore, 2020, 20). Insofar as contemporary democratic crises derive from citizens' resentment of failures of representative democracy's 'existing paradigm' to deliver the democratic promise of 'people's power' (Landemore, 2020, xiii), Landemore argues that embracing the revisionist ideals expressed through activist practice can help overcome crises, by marking out experimental instruments for regaining democratic control.

The other two books - Hope for Democracy, and Mending Democracy - say less about the abstract normative concepts and principles that make up theoretical 'ideals' or 'paradigms' of democracy, which are at the centre of analysis in Landemore's Open Democracy. Instead, their primary focus is on elaborating empirical analyses of concrete democratic practices that they see as promising correctives to the political drivers of democratic crises. In contrast to the architectural style of Landemore's conceptual design-thinking, Gastil and Knobloch in Hope for Democracy, alongside Hendriks, Ercan and Boswell in Mending Democracy, adopt a more engineering-style approach to democracy's current malfunctions - grounding their analysis in political problem-diagnostics, and detailing the institutional and civic processes in which they see strong potential for delivering workable solutions.

Gastil and Knobloch extend their established research on deliberative democratic innovations by presenting new analysis of how deliberative institutions and processes can combat those political pathologies widely identified as drivers for contemporary legitimacy crises: citizen feelings of disempowerment and alienation; the outsized influence of money in politics; the proliferation of manipulative rhetoric in place of facts and reasoned argument; the distortive machinations of professional campaign consultants; and enculturated partisan divides. Their analysis is developed through an interwoven series of narratives, centred on how organisers and participants in recent deliberative 'minipublic' initiatives in the United States have experienced and overcome the challenges posed by these familiar democratic pathologies. 
Hendriks, Ercan and Boswell $(2020,2)$ similarly organize their analysis around empirical thick description of the 'everyday political actors and practices' that they see as playing crucial roles in 'mending' the legitimacy of contemporary democracies. But whereas Gastil and Knobloch's analysis offers exploratory reflections on deliberative remedies to a wide range of purported democratic pathologies, Hendriks, Ercan and Boswell instead focus in depth on theorizing remedies to what they see as one crucial overarching problem: the erosion of political connections across the fabric of today's large-scale democratic systems, among citizens, representatives, and complex policy-making processes. In adopting this problem-driven approach to democratic theory-building, they describe their methodology variously as 'grounded', 'abductive', and 'interpretive' (Hendriks, Ercan and Boswell, 2020, chapter two) - thus situating their approach within a broad family of pragmatic and practicedependent theoretical traditions.

A shared recognition of the creativity of democratic practice shapes the contributions of these books not only through their methodological approaches, but also in the substance of the political pathways that they chart towards democratic revival. The sense in which each theoretical contribution aims to guide political thinking and action is not as directly prescriptive as the institutional blueprints or 'models' (Held, 2006) produced through some earlier approaches to democratic theory. Whereas theories aimed at elaborating ideal institutional 'models' invite citizens to reflect on their democratic orders from the perspective of grand structural design - in the manner of participants in hypothetical constitutional conventions - the perspective for reflection invited by these books is much more localised and dynamic. The political agents addressed by these theories are not assumed to possess the capability to restructure political orders in their entirety or for perpetuity; rather, the addressees are ordinary citizens, empowered only to make more modest contributions to complex and emergent processes of political evolution. As such, the instruments of democratic revival advanced in these books are located not only in the structures of formal and large-scale institutions, but just as importantly in the creative strategies, energies, and relationships of active citizens, across multiple sites of political engagement.

Of the three books, Landemore's Open Democracy gives the greatest attention to questions of large-scale institutional design - at least in the sense that her proposed conceptual reorientation of democratic projects towards more 'open' forms of representation has implications for how 'democratic institutions as a whole' (Landemore, 2020, 8) are designed 
to operate within each political context. By 'openness' here, she means 'general accessibility of power to ordinary citizens', whereby 'citizens can make their voices generally heard at any point in time and initiate laws when they are not satisfied with the agenda set by representative authorities' (Landemore, 2020, 11). Some of the key democratic instruments she proposes for fostering 'open' representation are institutional in character: at their centre is what she calls the 'open mini-public' - a randomly selected assembly engaged in some agenda-setting and lawmaking activities, and connected to the larger population via crowdsourcing platforms and other deliberative forums (Landemore, 2020, 13). But while she proposes some such ideas for new institutional initiatives, drawing inspiration from recent democratic experiments in Iceland and France, she does not attempt to translate these into any one-size-fits-all institutional blueprint, aspiring to widespread consolidation and enduring stability. Instead, she incorporates in her normative ideal of democratic 'openness' a temporal dimension of 'open-endedness', requiring 'adaptability and revisability' in the design of democratic institutions (Landemore, 2020,14). Moreover, she emphasizes that the applications of her normative ideal of 'open' democracy extend beyond the institutional realm - further shaping the democratic ethos that motivates individual political engagements, by cultivating 'open-mindedness' among citizens in opposition to narrow-minded partisanship (Landemore, 2020, 14).

Gastil and Knobloch's Hope for Democracy, and Hendriks, Ercan and Boswell's Mending Democracy, direct theoretical attention further away from the high-level design questions surrounding democratic constitutions, and towards the local forms of democratic deliberation and community organizing in which they see most promise for the reinvigoration of democratic life. Gastil and Knobloch centre their analysis on a study of institutionalized deliberative 'minipublic' initiatives of a similar kind to those examined previously in established literatures on deliberative democratic innovations: more specifically, they focus in detail on the experimental Citizens' Initiative Review in the United States - a process through which deliberative 'minipublics' inform citizens' legislative voting decisions. But their analysis here is novel in shifting focus from the institutional rules and procedures that structure deliberative innovations, to the individual 'civic innovators' whose creative political energies have enabled these projects to develop, evolve, and succeed in the face of the many systematic obstacles examined in the book. 
Henriks, Ercan and Boswell similarly examine innovative practices of democratic community organizing and informal collaboration between citizens and administrators - drawn from case-studies in Australia and Britain - which they see as embodying important forms of democratic political agency operating within and between the rule-based structures of formal institutions. Compared with the high-level institutional concerns of some earlier generations of democratic theory, and the gravity of contemporary concerns about democratic crises, they acknowledge that their cases may appear 'low-key, mundane, and even dinky'; but they contend that it is precisely in such 'everyday political actors and practices' - too often 'overlooked' by loftier theoretical preoccupations - that the most important work of 'democratic mending' can be accomplished (Hendriks, Ercan and Boswell, 2020, 2). Practices of democratic mending are characterized on their account by the ongoing dynamic creation of connective political relationships among individuals across multiple political roles, which they see as critical to the maintenance of democratic life: 'democratic repair work is not about institutional reform but about exercising agency, expressing creativity, and finding ingenious ways for citizens to engage in democratic processes' (Hendriks, Ercan and Boswell 2020, 4). In this way, they share in common with the other authors a central concern with understanding how democratic political agency is exercised and how it can be better nurtured and empowered, rather than looking to the mechanistic functioning of rule-based constitutions and decision procedures to secure or salvage democratic legitimacy.

\section{Theorizing democratic revival: Further questions on problem, normativity, and power}

Each of these books offers a wealth of insights about the challenges confronted by democrats in the complex and rapidly-changing political orders of the $21^{\text {st }}$ century, and the role that can be played by emergent and creative forms of political agency in repairing and rebuilding democratic life. But while their themes and analyses are highly suggestive, they also leave open a number of challenging questions about their prescribed political pathways to democratic revival, which point towards important new lines of inquiry for contemporary democratic theory.

The first of these open questions concerns the precise character of the political problem that motivates the turn away from theoretical focus on the rigid structures of democratic institutional models, towards the fluid dynamics of democratic agency. While each frames its contribution as a remedial response to some political problem of legitimacy crisis or decline, 
it remains ambiguous whether this motivating problem should be understood as endogenous or exogenous to political ideals of democracy. Of the three books, Landemore's acknowledges this ambiguity most directly, presenting her democratic solution to the purported problem of legitimacy crisis as merely exploratory: her proposed democratic innovations are worth implementing, she claims, just '[i]nsofar as we think that "more democracy" is at least worth exploring as a solution to the ills and indeed "crisis" of modern electoral democracy' (Landemore, 2020, 11). In this way she leaves open - in principle at least - the possibility that more-or-better democracy may not in fact provide the only or best available solution to this current legitimacy crisis. Gastil and Knobloch characterize the overarching political problem that their democratic innovations aim to solve as an erosion of 'reason' in public life - a diagnosis that does not in itself invoke specifically democratic commitments; but since it turns out on their account that these missing dimensions of 'reason' are precisely the same ones that they claim can be empowered through practices of democratic deliberation, the possibility of non-democratic (or even non-deliberative) solutions to contemporary legitimacy crises does not for them arise. Hendriks, Ercan and Boswell identify the political problem as an unravelling of connections among different agents and institutional functions, which are 'vital to the integrity of democratic fabric', as instruments 'for achieving democratic legitimacy at a large scale' (Hendriks, Ercan and Boswell, 2020, 6). But this formulation of the problem as one of 'democratic legitimacy' runs together the distinct normative ideas of 'democracy' and 'legitimacy', leaving it ambiguous whether legitimacy is understood as an exogenous political value that grounds and regulates democratic practice, or as an internal component of the democratic ideal.

Whichever way this ambiguity about the character of the motivating problem is resolved, challenging theoretical questions remain. The obvious advantage of treating the problem of legitimacy as exogenous to democratic ideals is that it can then provide grounds for preferring one interpretation of the democratic ideal over others: the right interpretation of the democratic ideal in a given context will be the one that best remedies the legitimacy problem under those prevailing political circumstances. The corresponding disadvantage is that it undercuts the assumption that the best remedies to the legitimacy problem must necessarily be democratic. Insofar as these books appeal to exogenous legitimacy problems to ground justifications for democratic innovations, they thus put in question the legitimacy of democracy itself; yet the enduring necessity of democracy for realizing legitimacy is for the 
most part still assumed as a starting point for their analyses, without entertaining seriously any normative challenges to the legitimacy of democratic practices.

If, on the other hand, the motivating problem of legitimacy is understood as endogenous to democratic projects - as an element of democratic systems that is itself constrained by democratic norms - then such challenges to the legitimacy of democratic projects will be ruled out from the start. But the difficulty in this case is explaining how appeal to a problem of legitimacy can help us to adjudicate between different interpretations of the democratic ideal, or argue for innovations in democratic practice, if the content of that problem must itself be defined with reference to some fixed democratic norms. If we are going to pursue an approach to democratic theory that responds to diagnosed legitimacy problems, we must then get much clearer about how exactly we understand the problem of legitimacy, and its relationship to democratic ideals. In doing so, there is significant scope for democratic theorists to engage productively with new work by realist and pragmatist theorists, who are working in parallel to better understand the problem of legitimacy driving contemporary democratic crises (Milstein, 2020; Fossen, 2019; Sleat, 2014; Rossi, 2012; Macdonald, 2018).

These ambiguities about the motivating political problem open up a second and closelyrelated question concerning the normativity of the democratic principles underlying the creative practices advanced in these books. The question of normativity asks: in virtue of what should these prescribed democratic principles and practices be supported by political agents? Each book allows that its democratic prescriptions may derive some normative force from non-democratic grounds - whether through the broad notions of 'reason' and 'rationality' referenced by Gastil and Knobloch, the normative reasons of 'legitimacy' invoked by Hendriks, Ercan and Boswell, or the 'epistemic' virtues of democratic decisionmaking appealed to by Landemore $(2020,7)$. But all avoid any systematic attempt to justify their prescribed democratic principles and practices in terms of non-democratic reasons. Instead, they address their analyses to existing democratic citizens, for whom the normative force of democratic commitments is assumed as a constitutive feature of their established political agency.

This approach leaves little room, however, for grappling with those dimensions of contemporary legitimacy crises that may derive from erosion of just such normative democratic commitments - whether to abstract democratic principles such as equality and 
inclusion, or to the concrete democratic practices enacted within the boundaries of status quo community memberships and institutional governance functions. Insofar as these new theories of democratic revival rely on the democratic commitments of real political agents for the normativity of their prescriptions, it would thus seem important to try and understand better the kind of creative reflexivity demanded from democratic political agents in times of democratic crisis and transformation - where threats to democratic faith form part of the normative landscape on which theoretical arguments must be built. This points to a further question for future theoretical work: how can democratic agents work creatively not only to revive the political systems connecting citizens to one another and to their shared institutions, but further to revive those waning normative commitments that constitute democratic agency itself? In answering this question, it may be helpful to re-examine and further develop some insights about the creative dimensions of democratic agency drawn from classical pragmatist traditions of democratic theory (Dewey, 1939) - to help better understand the normative grounds of democratic commitments within the complex and dynamic political systems that shape contemporary democratic life. ${ }^{3}$

This issue of democratic political agency is intertwined with a third important question raised by these books - concerning the forms of political power that shape possibilities for, and pathways towards, democratic revival. All of these books are focused on the dynamics of political change in democratic systems, and treat the political agency of committed democrats as primary drivers of revivalist political transformation; yet the power dynamics of relationships among agents and institutions in these systems receive little systematic analysis. The transformative engine of democratic political agency is for the most part discussed as though driven by the force of normative commitment - independent from material capabilities to control evolving political institutions and relationships, or engage in effective resistance against the anti-democratic forces gaining strength across many political contexts worldwide. The overriding tone is one of optimism and hope, with a dash of nostalgia evoking an understanding that democracy has been vibrant before and can become so again, if ordinary citizens can just be adequately inspired to embrace and deploy their existing creative powers. This notion, however, invites a sceptical challenge: if democratic vitality can be effectively restored through the everyday political work of committed citizens under

\footnotetext{
${ }^{3}$ I argue for a similar shift towards a stronger role for creative agency in grounding normative legitimacy in international institutions (Macdonald and Macdonald, 2020).
} 
prevailing material structures and distributions of power, then why do we not already see this happening more widely and to greater remedial effect?

In answering this question, hope and inspiration are not the only lessons we can draw from the study of democracy's more than two-millennia-long history; alongside periodic successes, democratic ideals have suffered many long periods of political obscurity - and the dynamics of political power relations must play an important role in any explanation as to why. Arguably the political ascendancy of liberal democratic practices in the late modern era has derived not only from the legitimacy produced by their representative institutions for channeling democratic agency; it has derived further from their institutional enmeshment with the powerful institutions of sovereign statehood - whereby representative decisionmaking processes have been able to harness states' substantial material powers as tools for implementing decisions and regulating power relationships within background social orders. Yet the hope invested in the revivalist capacities of the 'emergent' and 'creative' democratic practices advanced in these books is prompted in part by recognition of the declining capacities of state-based institutional structures, alone, to realize democratic ideals. While I think these authors are right to shift their focus from the institutional structures of statist democratic models, to the emergent practices of creative democratic agency, this shift must be accompanied by further theoretical reflection on its implications for the ongoing political challenge of regulating the distribution and exercise of political power across the democratic system. More work is needed here to establish: what or who can exercise the power required for entrenching protections for political equality, and mounting effective resistance against encroaching domination, in the political 'wild' of these creative democratic practices? In developing firmer theoretical understandings of these issues, important insights could potentially be drawn from engagement with new theoretical work on democracy and 'complexity' (Gaus, 2019), which gives some systematic attention to the distinctive democratic challenges of restraining domination and fostering empowerment within the dynamic political era of the $21^{\text {st }}$ century.

\section{Conclusion}

During times of disorienting political change, democratic theory has always had much to contribute to the work of activist politics, through recasting the intellectual frameworks that serve to guide the actions of individual citizens towards common normative purposes and 
coordinated political strategies. These three new books carry on this valuable tradition of problem-driven and action-oriented theoretical work; and each makes significant new contributions to democratic theory that deserve to be widely read. The tone of these books is overwhelmingly optimistic - geared towards celebrating and inspiring democratic action and innovation, and fostering a sense of political possibility. Though as we have seen here, they also raise some more uncomfortable questions concerning the political problems, normativity, and power dynamics that are implicated in the work of democratic revival. Taken together, these remaining theoretical questions point towards the potential value of developing a stronger dialogue between democratic theorists and new realist and pragmatist theorists, in order to help better integrate insights from across these literatures on the challenging political issues they share in common. In grappling with these persisting difficulties, however, democrats should still aim to preserve the strong sense of political possibility and moral purpose that all these books so admirably embody.

\section{References}

Della Porta, D (2013) Can Democracy be Saved?: Participation, Deliberation and Social Movements. Cambridge: Polity Press.

Della Porta, D (2020) How Social Movements Can Save Democracy: Democratic Innovations from Below. Cambridge: Polity Press.

Dewey J (1939) Creative democracy: the task before us. In: Boydston J (ed.) (1988) The Later Works of John Dewey. Carbondale, IL: Southern Illinois University Press.

Fossen, T (2019) Language and Legitimacy: Is Pragmatist Political Theory Fallacious?. European Journal of Political Theory, 18(2), 293-305.

Gaus, G (2019) What Might Democratic Self-Governance in a Complex Social World Look Like?. San Diego L. Rev., 56, 967.

Gastil, J \& Knobloch, K (2019) Hope for Democracy: How Citizens can Bring Reason Back into Politics. New York: Oxford University Press.

Held, D (2006) Models of Democracy. Stanford: Stanford University Press.

Hendriks, C, Ercan, S \& Boswell, J (2020) Mending Democracy: Democratic Repair in Disconnected Times. New York: Oxford University Press, USA.

Howell, W \& Moe, T (2020) Presidents, Populism, and the Crisis of Democracy. Chicago: University of Chicago Press. 
Lafont, C (2019) Democracy Without Shortcuts: A Participatory Conception of Deliberative Democracy. New York: Oxford University Press.

Landemore, H (2012) Democratic Reason: Politics, Collective Intelligence, and the Rule of the Many. Princeton: Princeton University Press.

Landemore, H (2020) Open Democracy: Reinventing Popular Rule for the Twenty-First Century. Princeton: Princeton University Press.

Levitsky, S \& Ziblatt, D (2018) How Democracies Die. New York: Broadway Books.

Macdonald, T (2018) Sovereignty, democracy, and global political legitimacy. In Brown, C \& Eckersley, R (ed.) The Oxford Handbook of International Political Theory, Oxford: Oxford University Press, 400.

Macdonald, T \& Macdonald, K (2020) Towards a 'Pluralist' World Order: Creative Agency and Legitimacy in Global Institutions. European Journal of International Relations, 26(2), 518-544.

Matsusaka, J (2020) Let the People Rule: How Direct Democracy Can Meet the Populist Challenge. Princeton: Princeton University Press.

Milstein, B (2020) Justification Crisis: Brexit, Trump, and Deliberative Breakdown. Political Theory, DOI: 0090591720968596.

Mounk, Y (2018) The People vs. Democracy: Why Our Freedom is in Danger and How to Save It. Cambridge, MA: Harvard University Press.

Norris, P (2011) Democratic Deficit: Critical Citizens Revisited. Cambridge: Cambridge University Press.

Papadopoulos, Y (2013) Democracy in Crisis?: Politics, Governance and Policy. New York: Palgrave Macmillan.

Przeworski, A (2019) Crises of Democracy. Cambridge: Cambridge University Press.

Rawls, J (2005) Political Liberalism. New York: Columbia University Press.

Rosenblum, N \& Muirhead, R (2020) A Lot of People are Saying: The New Conspiracism and the Assault on Democracy. Princeton: Princeton University Press.

Rossi, E (2012) Justice, Legitimacy and (Normative) Authority for Political Realists. Critical Review of International Social and Political Philosophy, 15(2), 149-164.

Runciman, D (2018) How Democracy Ends. London: Profile Books.

Sleat, M (2014) Legitimacy in Realist Thought: Between Mralism and Realpolitik. Political Theory, 42(3), 314-337. 
Tanasoca, A (2020) Deliberation Naturalized: Improving Real Existing Deliberative Democracy. New York: Oxford University Press.

Tormey, S (2014) The Contemporary Crisis of Representative Democracy. Democratic Theory, 1(2), 104-112. 


\section{University Library}

\section{- M M I N E R VA A gateway to Melbourne's research publications}

Minerva Access is the Institutional Repository of The University of Melbourne

Author/s:

Macdonald, T

Title:

Reviving democracy: Creating pathways out of legitimacy crises

Date:

2021-09-13

Citation:

Macdonald, T. (2021). Reviving democracy: Creating pathways out of legitimacy crises. EUROPEAN JOURNAL OF POLITICAL THEORY, 22 (1), pp.181-191. https:// doi.org/10.1177/14748851211020625.

Persistent Link:

http://hdl.handle.net/11343/292065 